\title{
Substitution of Percutaneous Ethanol Injection with a Low Molecular Weight Peptide Gel Mimicking Chemoembolization for Cancer Therapy
}

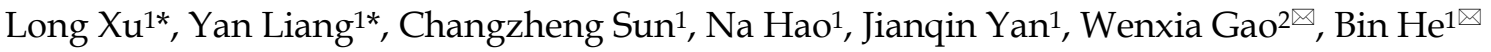 \\ 1. National Engineering Research Center for Biomaterials, Sichuan University, Chengdu 610064, China; \\ 2. College of Chemistry and Materials Engineering, Wenzhou University, Wenzhou 325027, China. \\ * These authors contributed equally to this work. \\ $\bowtie$ Corresponding authors: wenxiag@wzu.edu.cn (W. Gao); bhe@scu.edu.cn (B. He) \\ (C) Ivyspring International Publisher. This is an open access article distributed under the terms of the Creative Commons Attribution (CC BY-NC) license \\ (https://creativecommons.org/licenses/by-nc/4.0/). See http://ivyspring.com/terms for full terms and conditions.
}

Received: 2017.04.09; Accepted: 2017.05.27; Published: 2017.07.06

\begin{abstract}
In order to avoid the instability and quick separation between emulsifier and drug in the interventional chemoembolization, an injectable low molecular weight peptide gel (LMWG) was prepared to localize ethanol and chemotherapeutic for in situ synergistic therapy. The formation mechanism, rheological property and morphology of the LMWG were investigated by NMR, UV-vis, MS and SEM. The interaction between gelator and anticancer drug doxorubicin hydrochloride (DOX) was evaluated by fluorescence spectroscopy and its contribution on drug loading properties was demonstrated. The gel was non-toxic to both 3T3 fibroblasts and 4T1 breast cancer cells. DOX as well as ethanol were encapsulated in the gel and injected in breast cancer bearing mice with low drug dose $(2.5 \mathrm{mg} / \mathrm{kg}$ body weight). The LMWG surrounded tumors act as a depot for ethanol release and release DOX to induce the apoptosis of cancer cells. With the combination of percutaneous ethanol injection (PEI) and chemotherapy, the DOX loaded LMWG exhibited great significance in necrosis of tumor tissue and exciting tumor inhibition efficiency.
\end{abstract}

Key words: low molecular weight peptide gel, drug delivery, chemoembolization, percutaneous ethanol injection, in situ chemotherapy.

\section{Introduction}

Regional arterial infusion is often used in clinic for primary and secondary liver cancer therapy as the tumors are supplied almost exclusively by hepatic arterial flow unlike healthy liver tissue. 1, 2 Interventional embolization is the preferred treatment for unresectable liver cancer as well as arteriovenous malformations (AVMs) and aneurysms. ${ }^{3,} 4$ Transhepatic arterial chemoembolization (TACE) is an interventional embolization procedure, which is considered the main therapeutic tool for intermediate hepatocellular carcinoma (HCC $)^{5}$. In TACE, chemotherapeutic agents are infused via the hepatic arterial blood supply through a percutaneously placed transarterial catheter, and followed by selective arterial embolization of the tumor vascular supply. Embolization of the feeding arterial branches of HCC is expected to reduce vascularity and cause ischaemia of the tumor. ${ }^{6-9}$ The TACE utilizes the emulsion of a chemotherapeutic such as doxorubicin, cisplatin and mitomycin, and combined with an ethiodized oil to emulsify the drug and deliver to lesions. Unfortunately, the emulsion of lipiodol and drug is unstable and the two components are separated rapidly when the emulsion is injected into the hepatic arterial circulation to result in unfavourable pharmacokinetic profile as direct intra-arterial infusion of therapeutics. $7,8,10$

Microsphere embolization is a modified TACE to 
infuse hepatic arterial system. ${ }^{11-13}$ Drug-eluting polymer based microspheres were optimized to deliver drugs to tumors, the chemotherapeutics loaded microspheres achieved high intratumoral concentration and low plasma concentration to minimize systemic side-effects. ${ }^{14}$, 15 Embolization particles or gel foam were then used to reduce arterial inflow, induce tissue ischemia, and decrease the washout of the chemotherapeutic agents into the systemic circulation in order to prolong the contact time between cancer cells and drugs. ${ }^{16,17}$ Embolizing particles in the hepatic artery occluded nutrition supply to tumors.

Another technique for local chemotherapy is in situ therapy using injectable gel, the oppression of gel surrounded tumors promotes the ischemic necrosis of arteries and apoptosis of cancer cells. ${ }^{18-20}$ Low molecular weight gels (LMWGs) as substrates to trap anticancer drugs have attracted great interest for local chemotherapy in recent years due to their excellent in situ gelation characteristic via self-assembly. ${ }^{21-23}$ The complicated non-covalent interactions within the LMWGs including hydrogen bond, hydrophobic interaction, electrostatic interaction and $\Pi-\Pi$ interaction could not only drive the self-assembly of gelators but also inhibit the free diffusion of therapeutics in the three dimensional porous architectures to prevent the burst release of drug. The dissociation of LMWGs in vivo was regarded as degradation and the degraded small molecule gelators were easily metabolized. The drug loaded LMWGs were favorable for in situ chemotherapy like embolization. ${ }^{24,25}$

In this study, we developed a new dipeptide based gelator, the LMWG could be formed in ethanol. The LMWG was intratumorally injected to lock ethanol in or around tumors and maintain long-time high ethanol concentration to exert percutaneous ethanol injection (PEI) therapy. Chemotherapeutic doxorubicin hydrochloride was trapped in the LMWG for additional chemotherapy. The combination PEI and chemotherapy induced not only the vascular necrosis of tumor tissue but also the apoptosis of cancer cells to promote the therapeutic efficiency both in vitro and in vivo even with low DOX dose.

\section{Results and discussion}

\section{Characteristics of Gels}

The gelator (compound 3) exhibited excellent gelation in ethanol with the critical gelation concentration as low as $10 \mathrm{mg} / \mathrm{mL}$. Subtransparent gel was received from the transparent sol in ethanol (Figure 1A and 1B), and the drug-loaded gel was also obtained by cogelation of DOX and gelator (Figure 1C). Three-dimensional network consisted of nanofibers was observed in the SEM image (Figure 1D) of xerogel. The self-assembly of nanofibers was driven by the interactions of п-п stacking, hydrogen bond, van der Waals interaction within gelators, or between gelators and DOX molecules. It was further explained by fluorescence spectra in Figure 2 and ${ }^{1} \mathrm{H}$ NMR spectra in Figure 3.
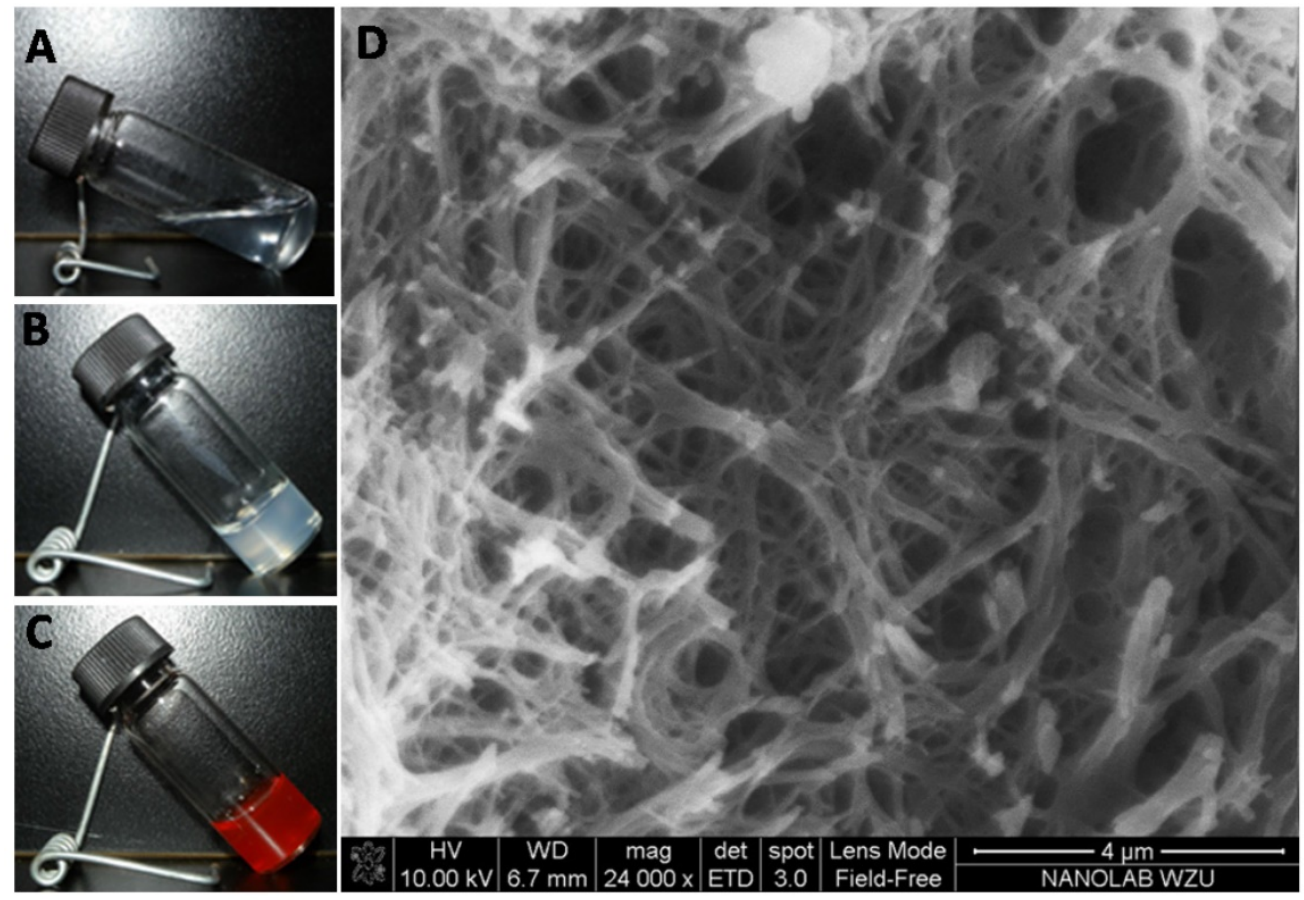

Figure 1. The image of (A) sol, (B) gel, and (C) DOX-loaded organogel; (D) SEM image of xerogel. 

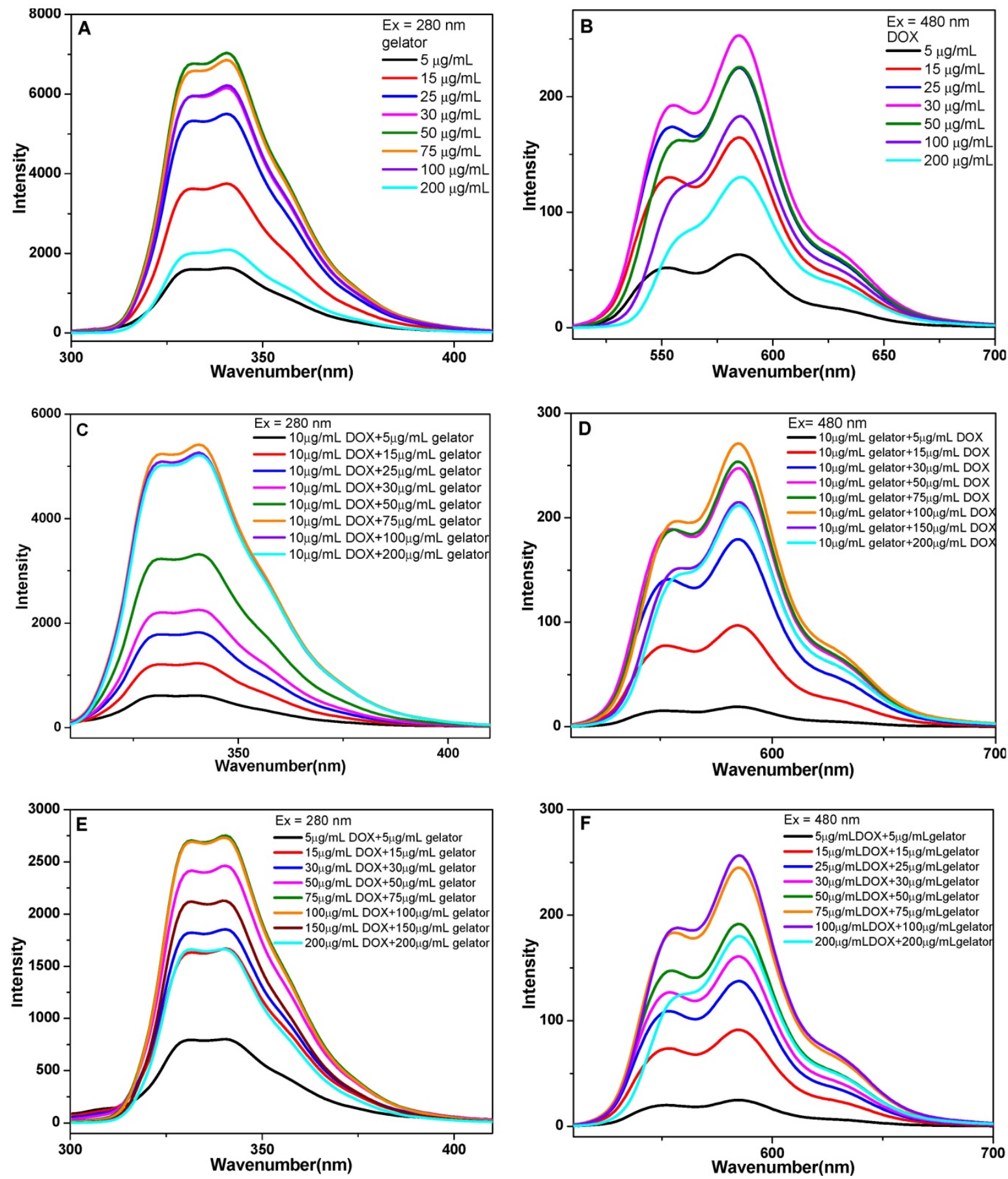

Figure 2. The fluorescence spectra of gelators and DOX in ethanol, excitation at $480 \mathrm{~nm}$ for the emission of DOX, excitation at $280 \mathrm{~nm}$ for the emission of gelator, (A) gelator in ethanol with different concentration, (B) DOX HCl solution with different concentration, (C) the emission of gelator and (D) the emission of DOX in the mixed solution of gelator with fixed concentration and $\mathrm{DOX} \cdot \mathrm{HCl}$ with different concentration, $(\mathrm{E})$ the emission of gelator and $(\mathrm{F})$ the emission of $\mathrm{DOX}$ in the mixed solution of gelator and $\mathrm{DOX} \cdot \mathrm{HCl}$ in ethanol (wtDOX.HCl:Wt gelator $=1: 1$ ).

The fluorescence spectra of gelators with different concentrations in ethanol showed that the fluorescence intensity increased with the gelator concentration increasing from 5 to $50 \mu \mathrm{g} / \mathrm{mL}$, and the fluorescence quenching occurred when the concentration of gelator was higher than $75 \mu \mathrm{g} / \mathrm{mL}$ (Figure 2A). The quenching indicated the formation of п-п stacking interaction between gelators. The fluorescence spectra of DOX showed the increase of DOX fluorescence when the concentration of DOX increased from 5 to $30 \mu \mathrm{g} / \mathrm{mL}$, and the quenching occurred when the concentration was higher than 50 $\mu \mathrm{g} / \mathrm{mL}$ (Figure 2B). The result implied that the п-п stacking interaction between gelators and DOX molecules was formed. In the mixed solutions of DOX $(10 \mu \mathrm{g} / \mathrm{mL})$ and gelator with different concentrations, 
the fluorescence intensity of gelator increased with the concentration increasing from 5 to $75 \mu \mathrm{g} / \mathrm{mL}$, and the quenching occurred when the concentration of gelator was higher than $100 \mu \mathrm{g} / \mathrm{mL}$ (Figure 2C). In the mixed solution of gelator $(10 \mu \mathrm{g} / \mathrm{mL})$ and DOX with different concentrations, the fluorescence intensity of DOX increased with the concentration increasing from 5 to $100 \mu \mathrm{g} / \mathrm{mL}$, and the quenching occurred when the concentration of DOX was higher than 150 $\mu \mathrm{g} / \mathrm{mL}$ (Figure 2D). In the mixture of gelator and $\mathrm{DOX} \cdot \mathrm{HCl}\left(w t_{\text {DOX.HCl: }}: w t_{\text {gelator }}=1: 1\right)$, the quenching for gelator or DOX appeared when the mixture concentration was higher than $100 \mu \mathrm{g} / \mathrm{mL}$ (Figure 2E, 2F). ${ }^{26,27}$

To investigate the self-assembly of gelators and the influence on rheological properties of the gels, ${ }^{1} \mathrm{H}$ NMR spectra of gelators at different concentrations and gelation time were presented in Figure S2. With the concentration of gelator increased from $5 \mathrm{mg} / \mathrm{mL}$ to $20 \mathrm{mg} / \mathrm{mL}$, the proton chemical shift of $\mathrm{N}-\mathrm{H}$ in serine shifted from $\delta=6.81 \mathrm{ppm}$ to $7.01 \mathrm{ppm}$, that of $\mathrm{N}-\mathrm{H}$ in phenylalanine shifted from $\delta=5.88 \mathrm{ppm}$ to 6.02 ppm, which indicated the presence of hydrogen bonds in the gel system. ${ }^{28}$ In addition, the chemical shift of protons in aromatic ring also shifted to lower field, indicating the $\Pi-\Pi$ stacking between aromatic rings. ${ }^{29}$ Moreover, the van der Waals interaction between gelators was an assistant driving force for the gel formation. ${ }^{30}$ The proton of methyne $c$ shifted to the lower field from $\delta=4.56 \mathrm{ppm}$ to $4.63 \mathrm{ppm}$, the proton of methyne e shifted down from $\delta=4.50 \mathrm{ppm}$ to 4.53 $\mathrm{ppm}$, and the methylene group $\mathrm{h}$ shifted down from $\delta=2.95 \mathrm{ppm}$ to $3.18 \mathrm{ppm}$, implying the presence of van de Waals in the gel system. The proton in methylene group i $(\delta=2.86 \mathrm{ppm})$ splitted from double peaks to multiple peaks with the increase of gelator concentration, which indicated that the free vibration of molecules were reduced as more molecules were involved in the self-assembly (Figure 3A). ${ }^{31,32}$ The ${ }^{1} \mathrm{H}$ NMR spectra of the gels with different gelation time were also available. In addition, the resonance signals of protons in aromatic moieties, $\mathrm{N}-\mathrm{H}$ groups, and $\mathrm{C}-\mathrm{H}$ groups were gradually shifted down field as the gelaton time was extended to $12 \mathrm{~min}$. The chemical shifts suggested the presence of $\mathrm{H}$-bonding and п-п stacking gradually strengthened the intermolecular interactions with the extension of gelation time. As the gelation time was further extended to $16 \mathrm{~min}$, no distinguished shift was observed as the sol was transformed to gel completely (Figure 3B).
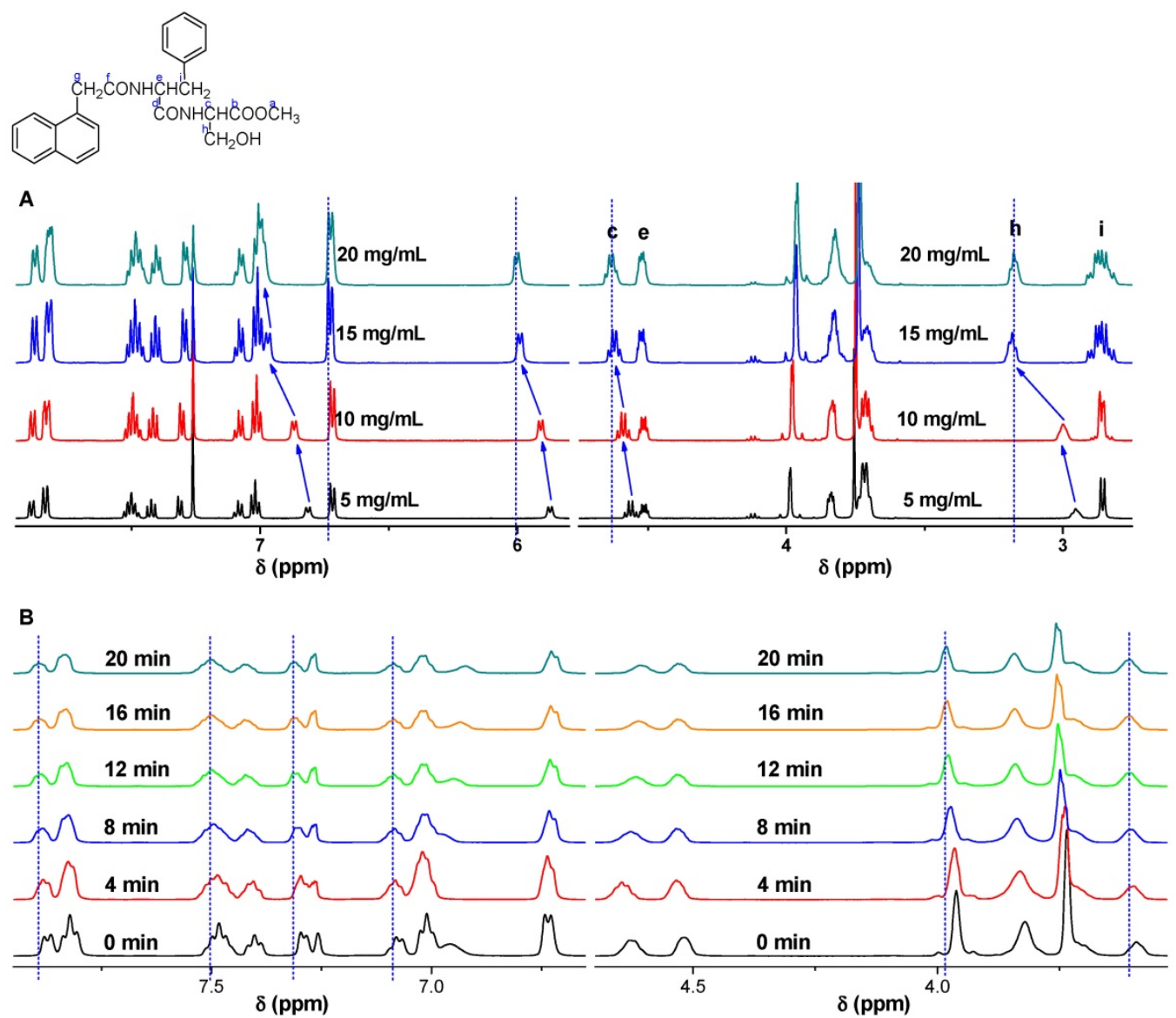

Figure 3. The $\mathrm{IH}$ NMR spectra of the gel at $25{ }^{\circ} \mathrm{C}$, (A) with different gelator concentrations of $5,10,15$ and $20 \mathrm{mg} / \mathrm{mL}$, (B) with different gelation time of $0,4,8,12$, $16,20 \mathrm{~min}$. 
The rheological properties of the gels were studied. The frequency dependence of storage modulus $\left(G^{\prime}\right)$ of the gels was higher than their corresponding loss modulus $\left(\mathrm{G}^{\prime \prime}\right)$, it demonstrated that real gels were formed (Figure 4A). ${ }^{33}, 34$ To the strain dependent storage, the $\mathrm{G}^{\prime}$ of the gel with concentration of $10 \mathrm{mg} / \mathrm{mL}$ was $1.39 \times 10^{3} \mathrm{~Pa}$, the $\mathrm{G}^{\prime}$ increased greatly to $3.44 \times 10^{4} \mathrm{~Pa}$ as the concentration increasing to $20 \mathrm{mg} / \mathrm{mL}$ with the same strain of $1 \%$. When the gel was subjected to a large strain of $50 \%$, the $G^{\prime}$ of these two gels decreased dramatically, it revealed that the network structure of the gels was destroyed (Figure 4B), but it could recover immediately after the stress was removed, $74.1 \%$ of the initial $G^{\prime}$ could be recovered in $5 \mathrm{~min}$. The rapid recovery capability was mainly attributed to the easy rearrangement of the physical interactions of hydrogen bond and п-п stacking interaction within the gel. This thixotropic LMWG showed
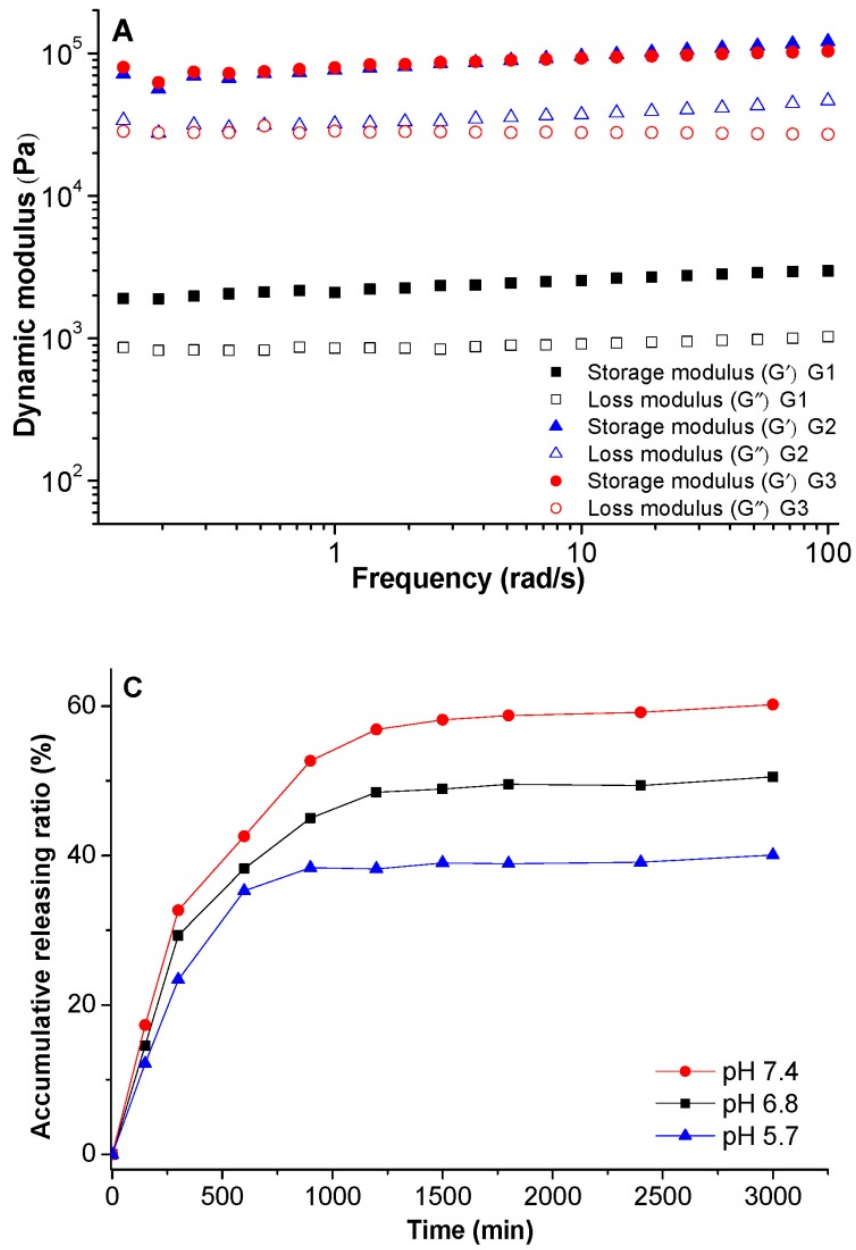

shear-thinning property and rapid recovery capability after the removal of the applied stress, this characteristic ensured the gel could be used for subcutaneous and intratumoral injection. Further investigation was carried out to the DOX-loaded gel (G3), little higher storage modulus was observed comparing to blank gel (G2). This property further ensured the injectable characteristic for subcutaneous, intratumoral and in vivo drug delivery applications. The gelation was formed in less than 10 min after the subcutaneous injection as shown in Figure 4D $(a, b)$, the gels formed both in subcutaneous and intratumoral injection. The release profile of DOX-loaded gel in different media indicated sustaining release of DOX, and the release rate increased in the medium with lower $\mathrm{pH}$ value (Figure 4C). The shape of gels was kept stable during the drug release, thus, the released DOX and ethanol could fulfill the combined effects of PEI and chemotherapy.
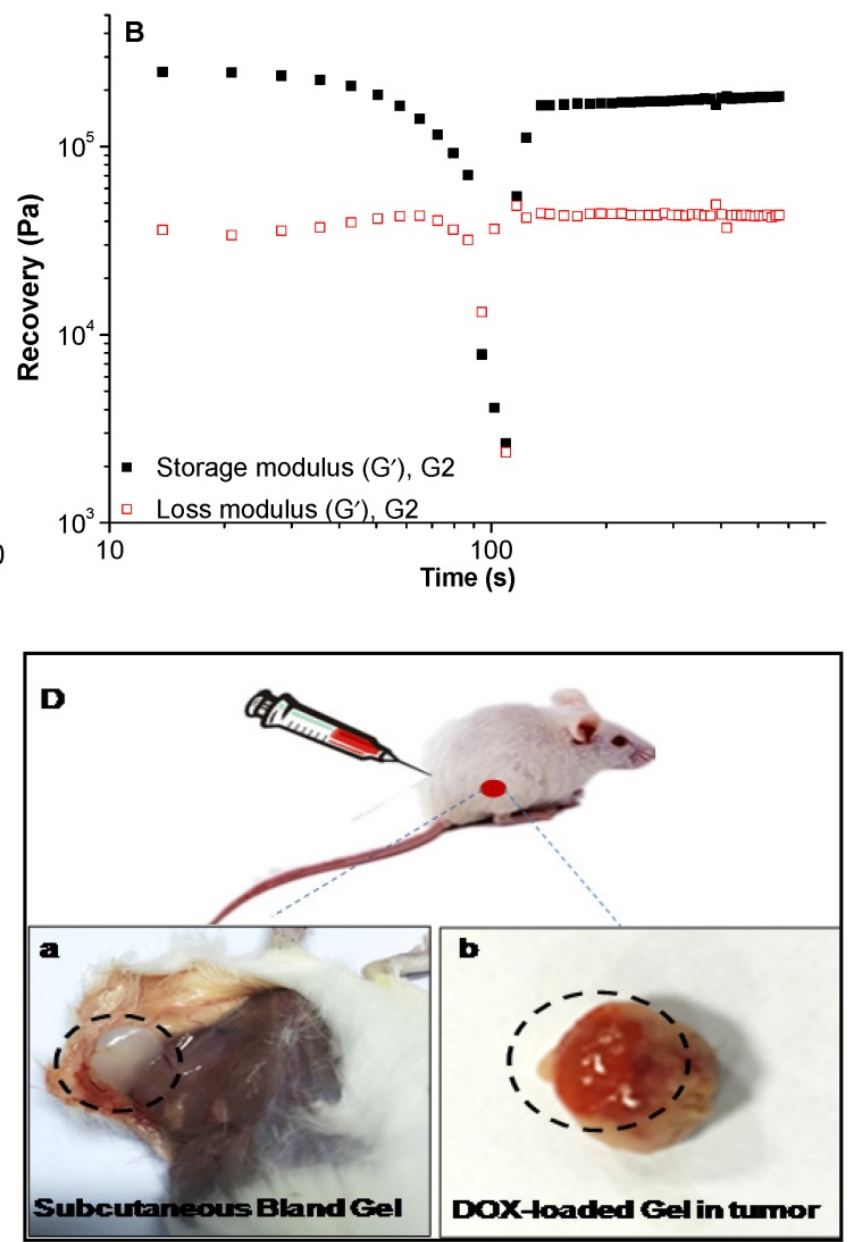

Figure 4. The rheological properties of gels, (A) storage and loss modulus as a function of angular frequency for the gels; (B) recovery of the gel, which was first subjected to a large strain of $50 \%$ for $130 \mathrm{~s}$ and then the recovery was probed at the strain of $0.1 \%$ and frequency of $1 \mathrm{rad} / \mathrm{s}$; (C) the release profile of DOX-loaded gel in different media, the data were expressed as mean \pm standard deviation $(n=3)$; (D) images of blank gel after subcutaneous injection (a), DOX-loaded gel injected in tumor (b). All the gels were measured at $25^{\circ} \mathrm{C}$. G1 and $\mathrm{G} 2$ were blank gels with the gelator concentration of $10 \mathrm{mg} / \mathrm{mL}$ and $20 \mathrm{mg} / \mathrm{mL}$ in ethanol, respectively; $\mathrm{G} 3$ was the DOX-loaded gel with the gelator concentration of $20 \mathrm{mg} / \mathrm{mL}$ and DOX concentration of $1 \mathrm{mg} / \mathrm{mL}$ in ethanol. 


\section{In vitro and In vivo evaluations}

The in vitro cytotoxicity test of the gels was evaluated using NIH/3T3 fibroblasts and 4T1 breast cancer cells (Figure 5A), the cells were incubated with the gel extract with the concentration of gelator from 0.5 to $5 \mathrm{mg} / \mathrm{mL}$. All the cell viabilities were higher than $90 \%$, which demonstrated that the gels were non-toxic to cells. The drug-loaded gel was administrated to investigate the therapeutic effect. Six groups of tumor-bearing BALB/c male mice were treated with different formulations (saline, ethanol, blank gel in ethanol, DOX-loaded gel in ethanol and free DOX). The tumor inhibition rate of these groups was showed in Figure 5B. The tumor volume increased rapidly for the saline group. The inhibition effects of both groups of free DOX $\cdot \mathrm{HCl}$ with low dose of $2.5 \mathrm{mg} / \mathrm{kg}$ via intratumoral and intravenous injiections were were unsatisfactory, however, the DOX-loaded gel group with the equivalent DOX dose of $2.5 \mathrm{mg} / \mathrm{kg}$ exhibited exciting inhibition efficiency. The drug was locked in the gel and maintained sustaining release around the tumor, with the combined PEI effect of ethanol locked in the gel to promote the dehydration and induce apoptosis of tumor cells, the group of DOX-loaded gel showed the best anticancer activity.

Other than the tumor inhibition rate, body weight loss of the formulations administrated tumor-bearing mice was also important to evaluate the therapeutic efficacy. No serious body weight decreases were observed in all the groups except the formulation of free $\mathrm{DOX} \cdot \mathrm{HCl}$ intravenously injected (Figure 5C). The survival rate of the tumor bearing mice were monitored (Figure 5D). All the mice in DOX-loaded gel group were survival for 30 days, which was the best within all the six groups. After 5 week's treatment, the survival rates for DOX-loaded gel, saline, blank gel, ethanol, DOX for intratumoral and intravenous injection were $75 \%, 12.5 \%, 25 \%, 50 \%$, $25 \%$ and $12.5 \%$, respectively. There was $25 \%$ mice survived only in the DOX-loaded gel group after 45 days. This suggested that the gel could reduce the systemic toxicity of DOX.
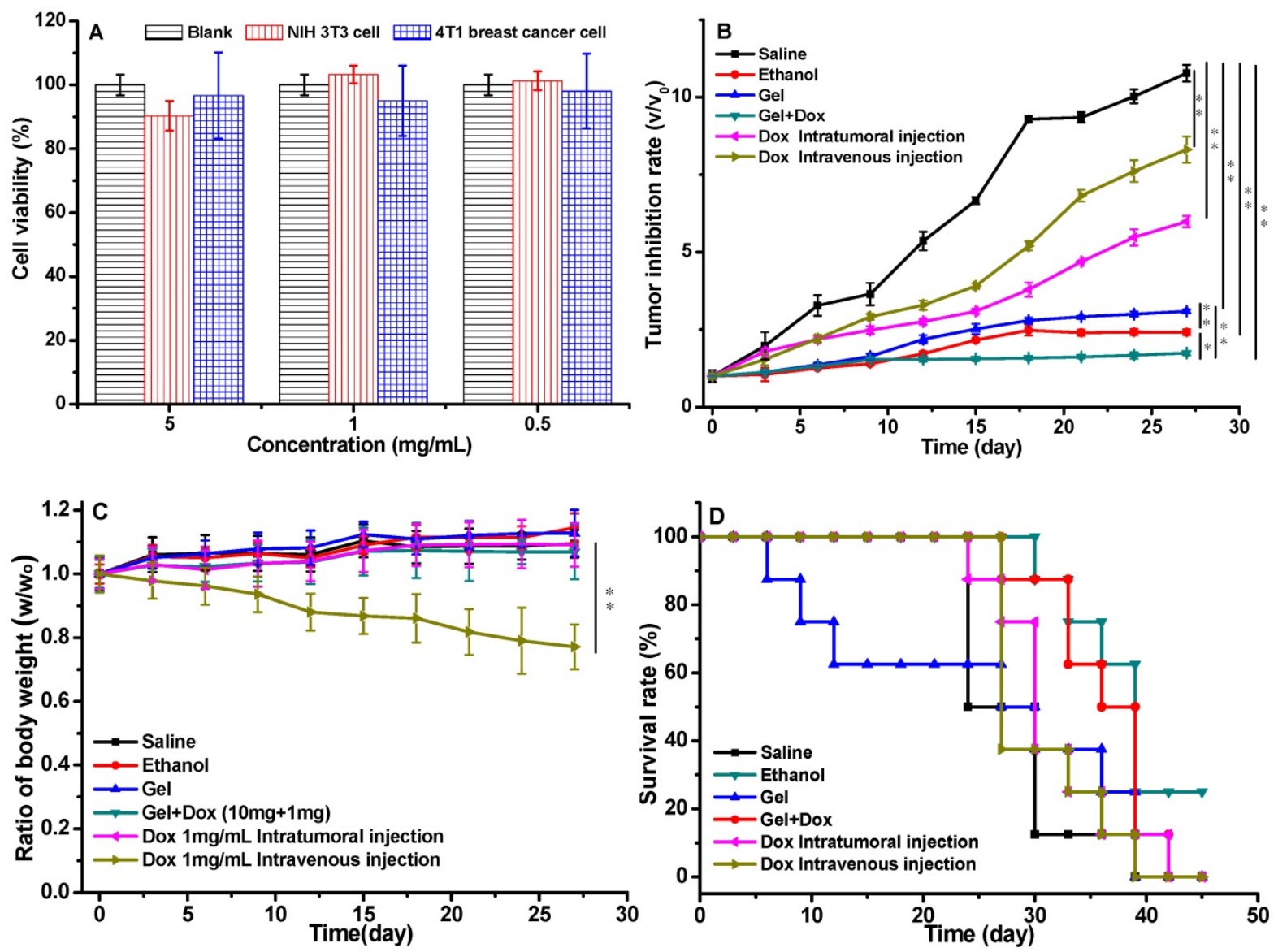

Figure 5. The in vitro cytotoxicity of gel and the in vivo anticancer activity of drug loaded gels, (A) the cytotoxicity of gelators incubated with NIH/3T3 cells and $4 \mathrm{~T} 1$ breast cancer cells, the data were expressed as mean \pm standard deviation $(n=5)$; (B) the volumes of tumors treated with drug loaded gels; (C) body weights of the mice treated with drug loaded gels; (D) survival rate of tumor-bearing mice; $\mathrm{P}$ values at 27 days. ( $\mathrm{P}<0.05 *, \mathrm{P}<0.01 * *$, $\mathrm{P}<0.001$ ***). a Group: saline; b Group: ethanol; c Group: blank gel; d Group: DOX-loaded gel; e Group: DOX $\cdot \mathrm{HCl}$ (intratumoral injection); f Group: DOX $\cdot \mathrm{HCl}$ (intravenous injection). All the groups were treated by intratumoral injection except for Group f. DOX equivalent dose of $2.5 \mathrm{mg} / \mathrm{kg}$ mice. Blank gel was compound 3 in ethanol (10 mg/mL), drug-loaded gel was compound $3(10 \mathrm{mg} / \mathrm{mL})$ and $\mathrm{DOX} \cdot \mathrm{HCl}(1 \mathrm{mg} / \mathrm{mL})$ in ethanol. 

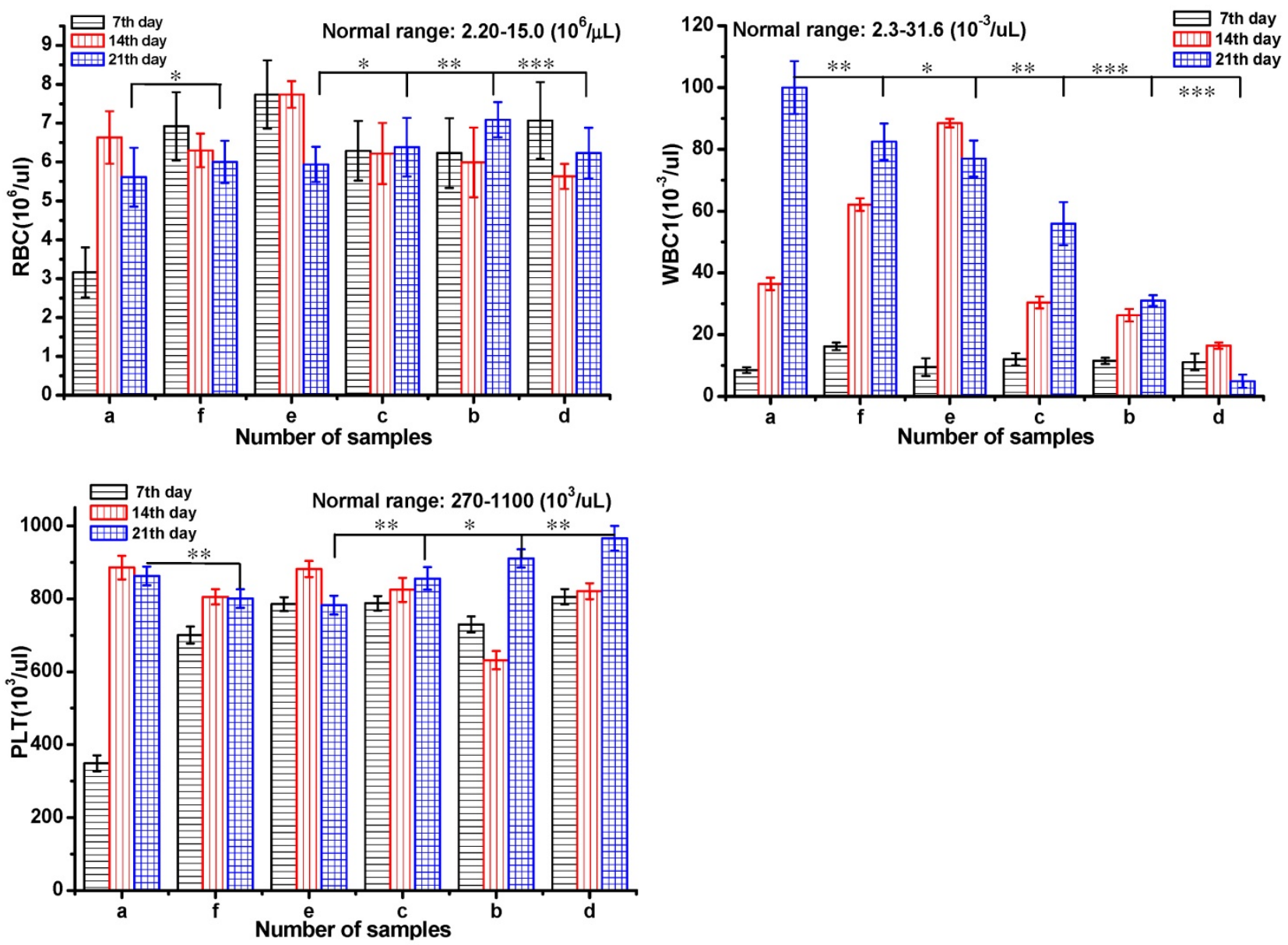

Figure 6. Test of blood routine of a Group: saline; b Group: ethanol; c Group: blank gel; d Group: DOX-loaded gel; e Group: DOX HCl (intratumoral injection); $f$ Group: DOX $\mathrm{HCl}$ (intravenous injection). All the groups were treated by intratumoral injection except for Group f. DOX equivalent dose of $2.5 \mathrm{mg}$ DOX/kg mice. All the groups except $\mathrm{h}$ group were injected via intratumor. The data were expressed as mean \pm standard deviation $(n=5)$

Serum biochemistry assays were also performed to assess the potential toxicity of DOX-loaded gel in Figure 6. Mice were sacrificed to collect the blood for serum biochemistry assays at day 7, 14 and 21 after injection. Blood of healthy mice injected with saline was set as control. Blood routine were investigated including red blood cell count (RBC), blood platelet count (PLT), white blood cell count (WBC). ${ }^{35}$ The RBC and PLT were in the normal range for all the groups after 21 day treatment. From day 14, the WBS of the groups $a, e$, and $f$ was out of normal range in different levels, which indicated the occurrence of inflammation. To the groups of $b$ and $d$, the index of WBC was normal during the 21 day treatment. These results implied that DOX-loaded gel could effectively inhibit inflammation and symptoms of congestion.

The histological tissues slides of tumors in the tumor-bearing mice at three phases were showed in Figure 7. The samples of DOX-loaded gel injected intratumorally showed much higher tumor inhibition effect (tumor images d, Figure 7) as the tumor necrosis with hemorrhage appeared in most areas (tumor images d, in III, Figure 7). In addition, the area of the tumor necrosis area increased rapidly (tumor images inI, II and III, Figure 7) with the increase of treatment time except saline group. Simultaneously, in saline group, little necrosis area in center of neoplastic cells was observed. Groups of b, c, e and $f$ had tumor necrosis in varying degrees with the increase of treatment time. These results further proved that DOX-loaded gel exhibited better inhibition effect on tumor.

Invasion and metastasis always accompanies with angiogenesis in the process of solid tumor growth. To investigate the antitumor efficacy and the tumor suppression mechanism, the CD31 and Ki-67 antigen staining were performed to assess the antitumor efficacy on tumor cell proliferation, and the terminal deoxynucleotidyl transferase-mediated dUTP nick end labeling (TUNEL) assay was employed to detect apoptotic programmed cell death as shown in Figure 8. The CD31 and Ki-67 immunohistochemical staining studies showed that the DOX-loaded gel resulted in the least number of 
microvessel density (MVD) and Ki-67-positive cells in all six groups. It suggested that the cell proliferation in DOX-loaded gel group was less active. In addition, from the CD31 and Ki-67 immunohistochemical staining studies, it showed that the number of MVD and Ki-67-positive cells decreased with increasing treatment time. About $42 \%$ of apoptotic cells in 7 day, $93 \%$ of apoptotic cells in 21 days were obtained in the tumor-bearing mice treated with DOX-loaded gel, it was the highest apoptosis among all the six groups. To the group d treated with DOX-loaded gel, partial tumor-bearing BALB/c male mice were cured after three weeks (Figure S3a). As the control, not only tumor cells rapidly proliferated and formed a large mass for the group treated with saline, serious inflammation were also occurred in liver and spleen (b, c and d in Figure S3). This result revealed the formulation of DOX-loaded gel was the most effective to induce the apoptosis of cancer cells. The inhibition of cancer cell proliferation was well as induction of apoptosis was the pathway of DOX-loaded gels to achieve significant anticancer activity.

\section{Experimental section}

\section{General materials and measurements}

All solvents and reagents were commercially available and chemical pure. a-Naphthaleneacetic Acid (NAA), L-serine and 1,1'-carbonyldiimidazole (CDI) were purchased from the Saen chemical technology (Shanghai) CO., LTD. L-phenylalanine and O-benzotriazole- $\quad N, \quad N, \quad N^{\prime}, \quad N^{\prime}$ -tetramethyluronium tetrafluoroborate (TBTU) were purchased from Shanghai Yuanju biotechnology CO., LTD. Doxorubicin hydrochloride $(\mathrm{DOX} \cdot \mathrm{HCl})$ was obtained from Zhejiang Hisun Pharmaceutical. All chemicals were used without purification.
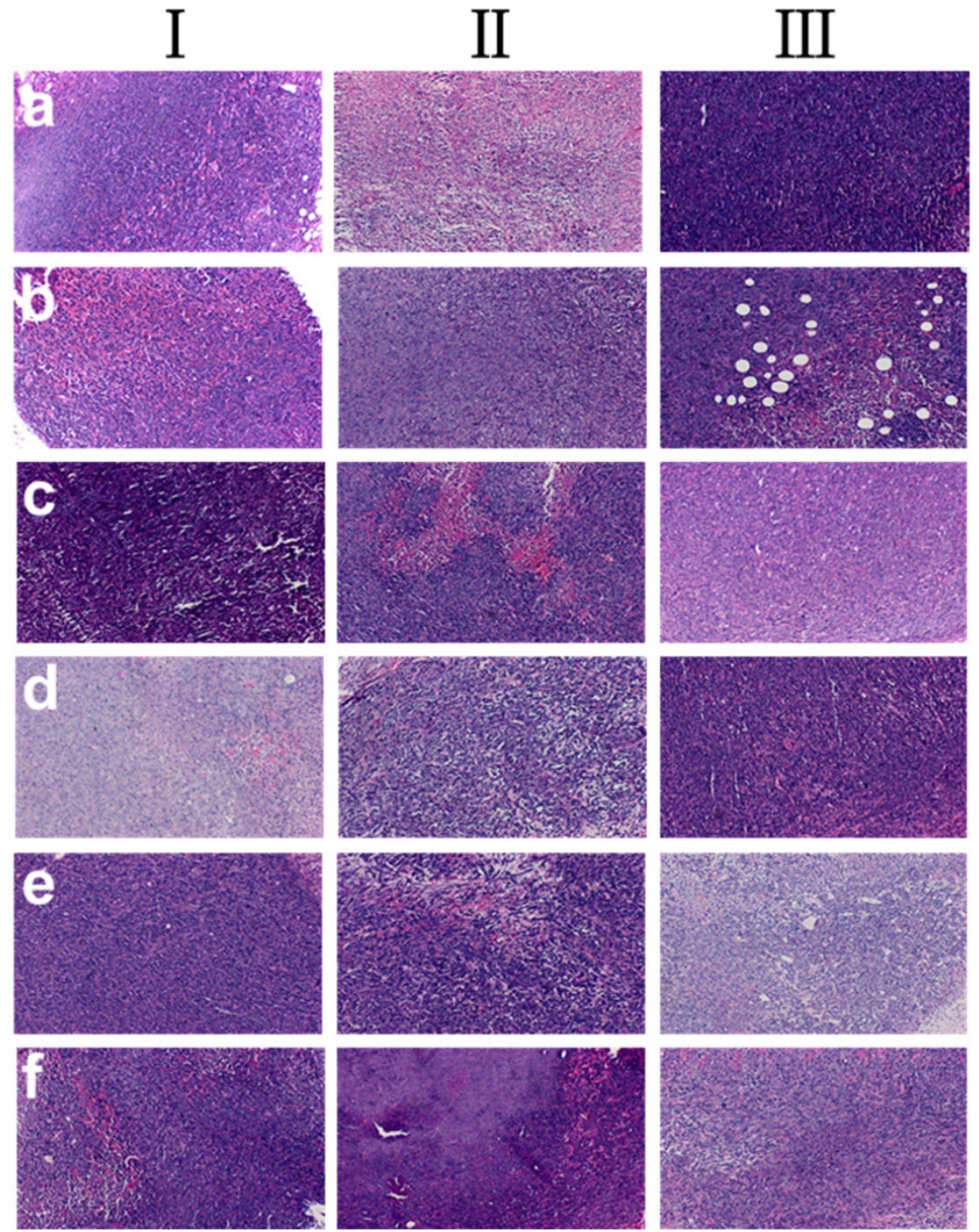

Figure 7. Histological analysis of tumors in tumor-bearing mice, a Group: saline; b Group: ethanol; c Group: blank gel; $d$ Group: DOX-loaded gel; e Group: DOX $\cdot \mathrm{HCl}$ (intratumoral injection); f Group: DOX $\cdot \mathrm{HCl}$ (intravenous injection). ( I : 7th day; II: 14th day; III: 21 th day) 

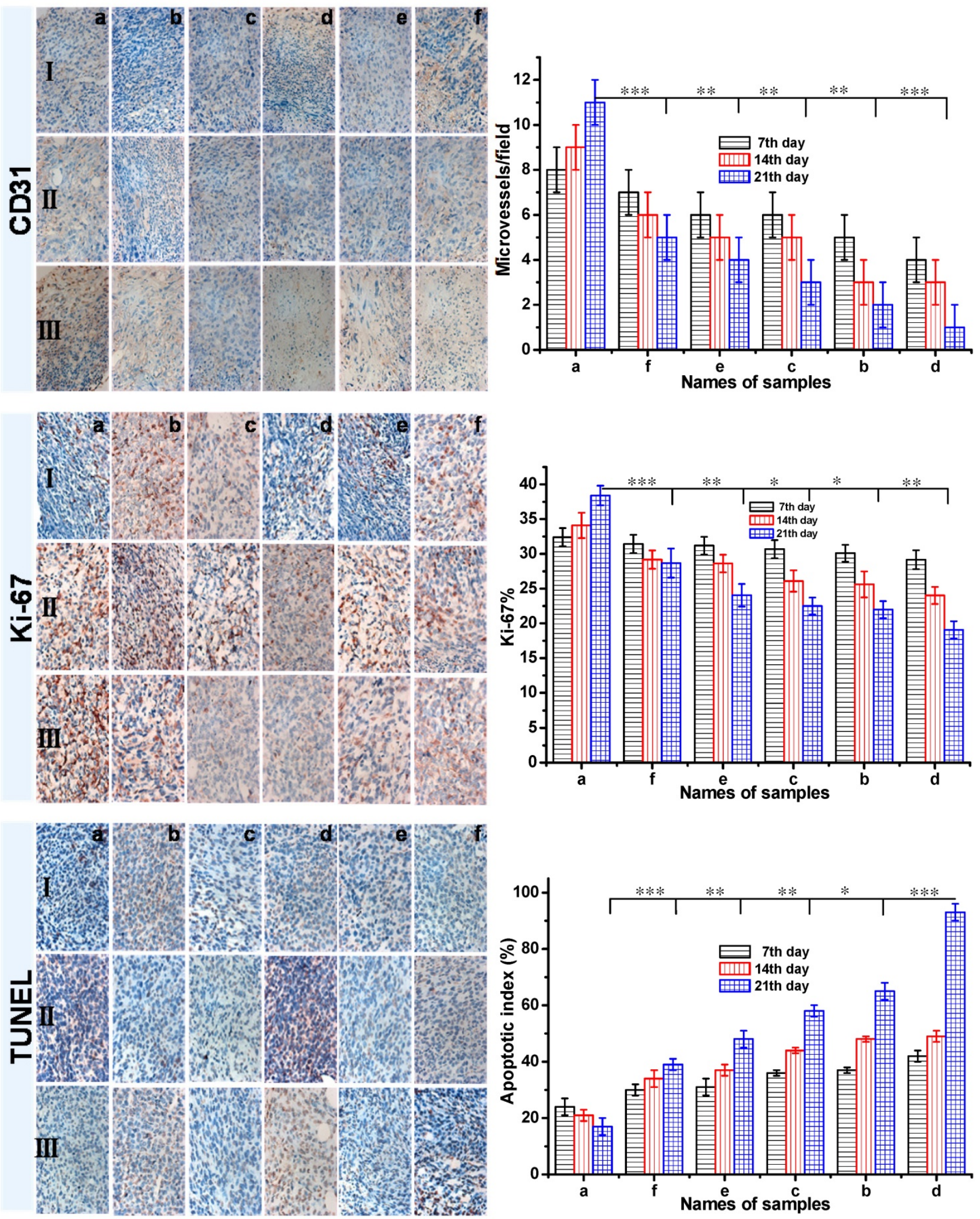

Figure 8. The CD31, Ki-67 and TUNEL immunohistochemical (IHC) staining of tumor tissues (all tissues: $\times 400$ ). The brown areas indicated CD31-positive, TUNEL-positive, or Ki-67-positive staining. Representative photomicrographs of 4T1 breast cancer cells harvested at the end of study from mice with various treatment: a Group: saline; b Group: ethanol; c Group: blank gel; $d$ Group: DOX-loaded gel; e Group: DOX HCl (intratumoral injection); $f$ Group: DOX HCl (intravenous injection). ( I : 7th day; II : 14th day; III: 21 th day) All the groups except group f were injected via intratumor. The CD31 positive area was expressed in endothelial cell pack and counted capillary number by reading each section (MVD). The Ki-67 density in each image was calculated by Ki-67-positive area/total area. The apoptotic index was calculated as a ratio of the apoptotic cell number to the total tumor cell number in each field of view. Data were presented as mean \pm SD $(n=5) .(P<0.05 *, P<0.01 * *, P<0.001 * * *)$ 
${ }^{1} \mathrm{H}$ NMR and ${ }^{13} \mathrm{C}$ NMR spectroscopy were performed on a Bruker- 500 spectrometer operating at $500 \mathrm{MHz}\left({ }^{1} \mathrm{H} \mathrm{NMR}\right)$ and $125 \mathrm{MHz}\left({ }^{13} \mathrm{C} \mathrm{NMR}\right)$, respectively. TMS (tetramethylsilane) was used as an internal standard. FT-IR spectra was recorded on a Bruker EQUINOX 55 spectrometer with the $\mathrm{KBr}$-technique. Mass spectrometric analysis was performed on Bruker microTOF-QII HR-MS analysis. Melting points were uncorrected and recorded on Digital Melting Point Apparatus WRS-1B. Scanning electronic microscopy (SEM) images were taken on a Nova NanoSEM 200 scanning electron microscope. UV spectra were recorded on a UV-2550 spectrometer (Shimadzu). The fluorescence spectrum was measured by HITACHI Fluorescence Spectrophotometer F-7000.

\section{Preparation of gelator}

The general procedure for synthesis of gelator was shown in Scheme 1.

Synthesis of compound 1, methyl-2-(2-(naphthalene-1-yl) acetamido-3-phenylpropanoate: L-Phenylalanine hydrochloride methyl ester $(7.45 \mathrm{~g}$, 1 eq, $34.54 \mathrm{mmol}$ ) was dissolved in dry THF $(40 \mathrm{~mL})$, triethylamine $(7.5 \mathrm{~mL}, 1.5 \mathrm{eq}, 52.10 \mathrm{mmol})$ was added dropwise at $0{ }^{\circ} \mathrm{C}$ and stirred for 10 minutes. NAA (7.08 g, $1.1 \mathrm{eq}, 38.00 \mathrm{mmol})$ and CDI $(8.40 \mathrm{~g}, 1.5 \mathrm{eq}$, $51.81 \mathrm{mmol})$ were dissolved in dry THF $(40 \mathrm{~mL})$ and stirred for 5 minutes. The activated solution was added dropwise to the mixture of $L$-phenylalanine hydrochloride methyl ester at $25{ }^{\circ} \mathrm{C}$ under $\mathrm{N}_{2}$ atmosphere for $6 \mathrm{~h}$. The reaction was monitored by thin layer chromatography (eluent phase: ethyl acetate: $\mathrm{MeOH}=8: 1$ ). THF was removed and $60 \mathrm{~mL}$ of $\mathrm{CHCl}_{3}$ was added to the mixture. The $\mathrm{CHCl}_{3}$ phase was washed with diluted hydrochloric acid and saturated $\mathrm{NaHCO}_{3}$, dried with anhydrous sodium sulfate. $\mathrm{CHCl}_{3}$ was removed by rotary evaporator to obtain compound 1, which was purified by column chromatography, yield $(29.72 \mathrm{~g}, 81 \%)$. White solid, mp: $125.4-126.4^{\circ} \mathrm{C} .{ }^{1} \mathrm{H}$ NMR (500 MHz, $\left.\mathrm{CDCl}_{3}, \mathrm{TMS}\right) \delta$ $2.86(\mathrm{dd}, 2 \mathrm{H}, \mathrm{J}=3.0,5.5 \mathrm{~Hz}), 3.60(\mathrm{~s}, 3 \mathrm{H}), 3.99(\mathrm{dd}, 2 \mathrm{H}$, $\mathrm{J}=16.0,55.0 \mathrm{~Hz}), 4.80-4.84(\mathrm{~m}, 1 \mathrm{H}), 5.72(\mathrm{~d}, 1 \mathrm{H}, \mathrm{J}=8.0$ $\mathrm{Hz}), 6.51(\mathrm{~d}, 2 \mathrm{H}, \mathrm{J}=7.5 \mathrm{~Hz}), 6.93(\mathrm{t}, 2 \mathrm{H}, \mathrm{J}=7.5 \mathrm{~Hz}), 7.04$ $(\mathrm{t}, 1 \mathrm{H}, \mathrm{J}=7.5 \mathrm{~Hz}), 7.32(\mathrm{~d}, 1 \mathrm{H}, \mathrm{J}=7.0 \mathrm{~Hz}), 7.40(\mathrm{t}, 1 \mathrm{H}$, $\mathrm{J}=7.5 \mathrm{~Hz}), 7.50-7.53(\mathrm{~m}, 2 \mathrm{H}), 7.81(\mathrm{~d}, 1 \mathrm{H}, \mathrm{J}=10.5 \mathrm{~Hz})$, $7.88(\mathrm{dd}, 1 \mathrm{H}, \mathrm{J}=3.5,6.5 \mathrm{~Hz}), 7.92(\mathrm{dd}, 1 \mathrm{H}, \mathrm{J}=3.5,6.5$ $\mathrm{Hz}) .{ }^{13} \mathrm{C}$ NMR $\left(125 \mathrm{MHz}, \mathrm{CDCl}_{3}, \mathrm{TMS}\right) \delta(37.5,41.6$, $52.2,52.7,123.8,125.6,126.2,126.8,126.8,128.3,128.3$, $128.5,128.8,128.8,130.7,132.0,134.0,135.2,170.3$, 171.5). HRMS (ESI+) calcd for $\left(\mathrm{C}_{22} \mathrm{H}_{22} \mathrm{NO}_{3}\right)^{+}: 348.1594$; found: 348.1592 .

Synthesis of Compound 2, 2-(2-(naphthalene-1yl)acetamido-3-phenylpropanoic acid (1-NapF): Compound 1 ( $4.00 \mathrm{~g}, 1 \mathrm{eq}, 11.51 \mathrm{mmol})$ was dissolved in the mixture of methanol and THF (v:v $=5: 1,60 \mathrm{~mL})$, $1.0 \mathrm{M} \mathrm{NaOH}(13.8 \mathrm{~mL}, 1.2 \mathrm{eq}, 13.8 \mathrm{mmol})$ was added dropwise at $0{ }^{\circ} \mathrm{C}$. The mixture was stirred for $4 \mathrm{~h}$ at 25 ${ }^{\circ} \mathrm{C}$. The hydrolysis was monitored by thin layer chromatography. The solvent was evaporated and the residuum was acidified to $\mathrm{pH}=2$ with $1 \mathrm{M} \mathrm{HCl}$. The solid was separated and dried overnight under vacuum to obtain compound 2 (yield: $3.49 \mathrm{~g}$, 91\%). White solid, mp192.6-193.3 ${ }^{\circ} \mathrm{C} .{ }^{1} \mathrm{H}$ NMR $(500 \mathrm{MHz}$, $\left.\mathrm{CDCl}_{3}, \mathrm{TMS}\right) \delta 2.91(\mathrm{~s}, 2 \mathrm{H}), 3.92(\mathrm{~d}, 1 \mathrm{H}, \mathrm{J}=19.0 \mathrm{~Hz})$, $4.04(\mathrm{~d}, 1 \mathrm{H}, \mathrm{J}=16.5 \mathrm{~Hz}), 4.80(\mathrm{dd}, 1 \mathrm{H}, \mathrm{J}=6.0,13.5 \mathrm{~Hz})$, $5.84(\mathrm{~d}, 1 \mathrm{H}, \mathrm{J}=8.0 \mathrm{~Hz}), 6.57(\mathrm{~d}, 2 \mathrm{H}, \mathrm{J}=7.5 \mathrm{~Hz}), 6.92(\mathrm{t}$, $2 \mathrm{H}, \mathrm{J}=7.5 \mathrm{~Hz}), 7.03(\mathrm{t}, 1 \mathrm{H}, \mathrm{J}=7.5 \mathrm{~Hz}), 7.25-7.28(\mathrm{~m}, 1 \mathrm{H})$, $7.38(\mathrm{t}, 1 \mathrm{H}, \mathrm{J}=7.5 \mathrm{~Hz}$ ), 7.49 (quint, 1H, J=7.0 Hz), 7.81 $(\mathrm{d}, 1 \mathrm{H}, \mathrm{J}=8.0 \mathrm{~Hz}), 7.87(\mathrm{t}, 2 \mathrm{H}, \mathrm{J}=7.5 \mathrm{~Hz}), 8.97(\mathrm{~s}, 1 \mathrm{H}) \cdot{ }^{13} \mathrm{C}$ NMR $\left(125 \mathrm{MHz}, \mathrm{CDCl}_{3}, \mathrm{TMS}\right) \delta(37.0,41.2,52.9,123.7$, $125.6,126.3,126.9,126.9,128.4,128.4,128.6,128.8$, 128.9, 130.2, 132.0, 134.0, 135.0, 171.7, 174.4). HRMS $\left(\mathrm{ESI}^{+}\right)$calcd for $\left(\mathrm{C}_{21} \mathrm{H}_{20} \mathrm{NO}_{3}\right)^{+}$: 334.1438; found: 334.1460 .

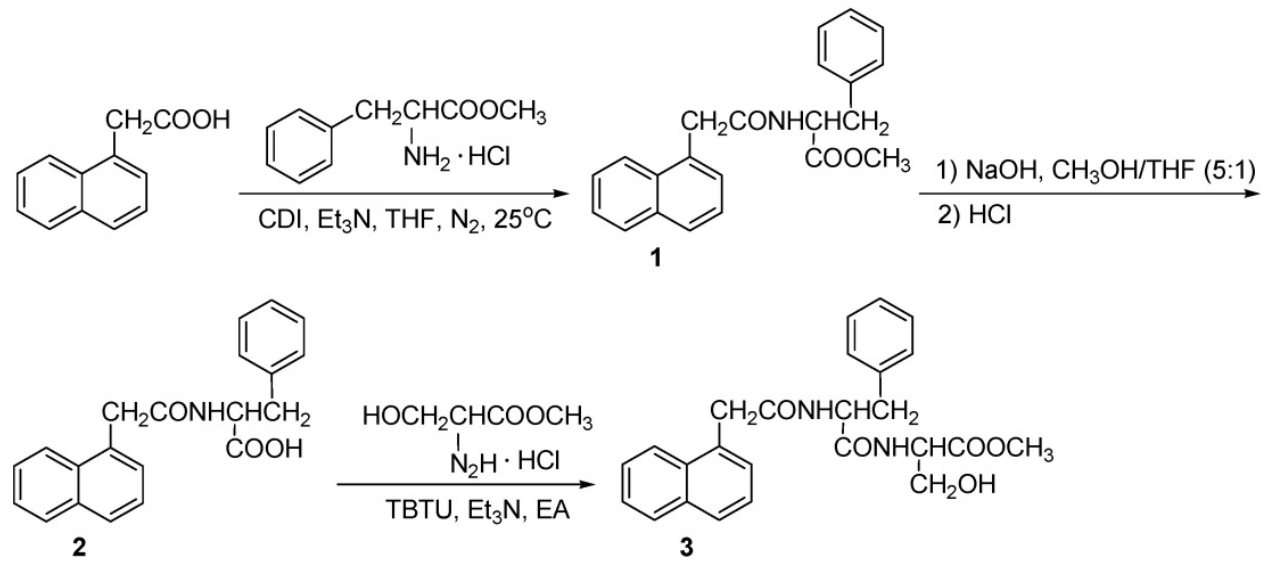

Scheme 1. The synthesis of dipeptide gelator (compound 3) 
Synthesis of Compound 3: TBTU (3.23 g, $10 \mathrm{mmol})$ was added to the mixture of compound $2(3.33 \mathrm{~g}$, 1eq, $10 \mathrm{mmol})$ and triethylamine $(2.7 \mathrm{~mL}, 20 \mathrm{mmol})$ in 50 $\mathrm{mL}$ ethyl acetate, and stirred at room temperature for 10 minutes. Serine methyl ester hydrochloride ( $3.11 \mathrm{~g}$, $2 \mathrm{eq}, 20 \mathrm{mmol}$ ) was added into the solution and stirred at room temperature for $10 \mathrm{~h}$. The mixture was filtered and the solid was reprecipitated in propyl alcohol to obtain compound 3 (yield: 30\%). White solid, mp: 209.1-210.7 ${ }^{\circ} \mathrm{C}$. ${ }^{1} \mathrm{H}$ NMR $(500 \mathrm{M} \mathrm{Hz}$, DMSO- $d_{6}$, TMS) $\delta 2.78(\mathrm{dd}, 1 \mathrm{H}, \mathrm{J}=10.5,13.35 \mathrm{~Hz}), 3.06$ $(\mathrm{dd}, 1 \mathrm{H}, \mathrm{J}=3.5,13.5 \mathrm{~Hz}), 3.64(\mathrm{~s}, 3 \mathrm{H}), 3.86(\mathrm{dd}, 2 \mathrm{H}$, $\mathrm{J}=15.0,27.0 \mathrm{~Hz}), 4.35(\mathrm{~d}, 1 \mathrm{H}, \mathrm{J}=4.0 \mathrm{~Hz}), 4.37-4.40(\mathrm{~m}$, $1 \mathrm{H}), 4.67-4.71(\mathrm{~m}, 1 \mathrm{H}), 5.09(\mathrm{t}, 1 \mathrm{H}, \mathrm{J}=5.5 \mathrm{~Hz}), 7.19-7.30$ $(\mathrm{m}, 6 \mathrm{H}), 7.36(\mathrm{t}, 1 \mathrm{H}, \mathrm{J}=7.5 \mathrm{~Hz}), 7.41(\mathrm{t}, 1 \mathrm{H}, \mathrm{J}=7.5 \mathrm{~Hz})$, $7.48(\mathrm{t}, 1 \mathrm{H}, \mathrm{J}=7.5 \mathrm{~Hz}), 7.77(\mathrm{~d}, 1 \mathrm{H}, \mathrm{J}=8.0 \mathrm{~Hz}), 7.86(\mathrm{dd}$, $1 \mathrm{H}, \mathrm{J}=8.0,13.5 \mathrm{~Hz}), 8.42(\mathrm{~d}, 1 \mathrm{H}, \mathrm{J}=10.5 \mathrm{~Hz}), 8.50(\mathrm{~d}, 1 \mathrm{H}$, $\mathrm{J}=7.5 \mathrm{~Hz}) .{ }^{13} \mathrm{C}$ NMR $\left(125 \mathrm{MHz}\right.$, DMSO- $\left.d_{6}, \mathrm{TMS}\right) \delta$ $(25.5,37.7,51.8,53.6,54.7,61.2,124.2,125.4,125.5$, $125.9,126.2,126.9,127.6,127.9,128.2,129.3,131.9$, 132.5, 133.2, 137.8, 169.8, 170.9, 171.6). FT-IR (KBr): 3435.8, 3297.8, 1739.0, 1640.7, 1539.2, 1219.7, 1053.6 $\mathrm{cm}^{-1}$, HRMS $\left(\mathrm{ESI}^{+}\right)$calcd for $\left(\mathrm{C}_{22} \mathrm{H}_{27} \mathrm{~N}_{2} \mathrm{O}_{5}\right)^{+}: 435.1914$; found: 435.1926 .

\section{Gel preparation}

A weighed amount of gelator in ethanol $(1.0 \mathrm{~mL})$ was placed in a flask fitted with a reflux condenser and heated until dissolved completely. The solution was transferred into a closed glass vial while cooling to room temperature. The gel was received at room temperature. The critical gelation concentration (CGC) was determined by measuring the minimum amount of gelator in the formation of a stable gel at 25 ${ }^{\circ} \mathrm{C}$. DOX-loaded gel was prepared by adding $\mathrm{DOX} \cdot \mathrm{HCl}(1.0 \mathrm{mg})$ into the solution of gelator $(10.0$ $\mathrm{mg}$ ) in ethanol $(1.0 \mathrm{~mL})$, and cooled to room temperature. The xerogels for SEM were obtained from the organogels, which were dried at room temperature in vacuum.

\section{Cytotoxicity test}

Mouse fibroblasts NIH/3T3 and 4T1 breast cancer cells were incubated with the extracts of gelators to evaluate the cytotoxicity of the gel. The $\mathrm{NIH} / 3 \mathrm{~T} 3$ cells and 4T1 breast cancer cells were harvested and seeded in 96-well plates with $100 \mu \mathrm{L}$ mediums for $24 \mathrm{~h}$ incubation. The extracts of gelators were filtered and added to the cells. After incubated for $48 \mathrm{~h}$, the culture medium was removed and the wells were washed with PBS ( $\mathrm{pH}=7.4)$. CCK-8 in DMEM (10\%) was added to each well. After additional $4 \mathrm{~h}$ incubation, the cell viability was determined by measuring the absorption at $450 \mathrm{~nm}$ using a microplate reader (Thermo Scientific MK3). ${ }^{36}$
The extracts of gelators were prepared in accordance with International Organization for Standardization (ISO) tests (ISO 10993-5) with different gelator concentrations $(0.5,1$, and $5 \mathrm{mg} / \mathrm{mL})$ in complete culture medium at $37^{\circ} \mathrm{C}$ for $24 \mathrm{~h}$.

\section{In vivo antitumor activity}

All animal experiments were performed in line with animal experiments ethical committee for care and use of research animals. Male BALB/c mice (body weight: 18-22 g) were purchased from West China Animal Culture Center of Sichuan University. $\mathrm{BALB} / \mathrm{c}$ mice were injected subcutaneously with $5 \times 10^{5} 4 \mathrm{~T} 1$ breast cancer cells into right flank. When the inoculated tumor volume reached $100-200 \mathrm{~mm}^{3}$, the mice were randomly divided into six groups. Ten tumor-bearing BALB/C male mice were randomly assigned to each group. One group was injected intravenously via the tail vein with free $\mathrm{DOX} \cdot \mathrm{HCl}$ of $2.5 \mathrm{mg} / \mathrm{kg}$ body weight dose as control. All the other groups were injected intratumorally with saline, ethanol, free DOX $(2.5 \mathrm{mg} / \mathrm{kg}$ body weight), blank gel in ethanol, DOX-loaded gel in ethanol with DOX dose of $2.5 \mathrm{mg} / \mathrm{kg}$ body weight. All samples were injected for three times, the body weights of mice and the tumor volumes were measured at 3-day interval. The behaviors of mice were determined by the animal healthcare technicians. Tumor volumes were calculated using the formula $\mathrm{V}=\left(\mathrm{a} \times \mathrm{b}^{2}\right) / 2(\mathrm{a}$ is the largest diameter, $\mathrm{b}$ is the smallest diameter). ${ }^{37}$

The mice in all groups were randomly picked out and sacrificed at day 7, 14, and 21 after the injection, tumor tissues were taken out and fixed in $4 \%$ formaldehyde, processed routinely into paraffin, sectioned, stained with hematoxylin and eosin (H\&E) and examined by a digital microscope.

\section{Immunohistochemical analysis of CD31, Ki-67 and TUNEL}

Streptavidine peroxidase methods were specially designed for Immunohistochemical (IHC) reactions and other immune detection. ${ }^{38}$ The paraffin-embedded tumor sections were deparaffinaged, rehydrated and incubated overnight at $4{ }^{\circ} \mathrm{C}$ with primary monoclonal antibody against CD31 or Ki-67 (1:200) (British abcam-(Shanghai) trading Co., LTD). Biotinylated goat antirabbit antibodies were used as secondary antibodies at 1:200 for $30 \mathrm{~min}$ at $25{ }^{\circ} \mathrm{C}$ and the egg protein reagent marked with horseradish peroxidase was added. The data of immunohisto- chemistry staining was obtained as described. IHC images were taken by the Motic Images Advanced software (Motic China Group CO., LTD.), the positive-stained integrated optical density (IOD) of the CD31 and Ki-67 was 
scaled in each image by Image-Pro Plus 6.0 software (Media Cybernetics, Bethesda, MD). The microvessel density (MVD) was counted by reading each section which referenced Weidner method for quantitative analysis, and the CD31 positive area was expressed in endothelial cell pack. In addition, the Ki-67 density in each photograph was calculated as the ratio of Ki-67-positive area to total area. For terminal deoxynucleotidyl transferase mediated UTP nick end labeling (TUNEL) assay, the dewaxed and rehydrated tumor tissue sections were incubated with proteinase $\mathrm{K}$ at $37{ }^{\circ} \mathrm{C}$ for $15 \mathrm{~min}$, rinsed with PBS twice. The TUNEL assay was performed on in situ cell death detection kit-POD (Roche Group, Switzerland) to evaluate apoptotic cells. Positive TUNEL staining was visualized by optical microscopy and the apoptotic index was formulated as the ratio of apoptotic cell number to total tumor cell number in each microscope field.

\section{Statistical analysis}

Data were analyzed using Prism 4 (Graph Pad Prism 5 Software, San Diego, CA) and expressed as mean \pm standard (SD) deviation. Multiple groups were compared using one-way ANOVA. Two groups were compared using T-test. Statistical significance was set at $\mathrm{p}<0.05$.

\section{Conclusion}

A synergistic interventional therapy of an in situ injectable low molecular weight peptide gel was investigated in this paper. Low dose of anticancer drug doxorubicin hydrochloride $(2.5 \mathrm{mg} / \mathrm{kg}$ body weight) and ethanol were encapsulated in the gel, the in vivo anticancer activity was carried out in breast cancer bearing mice via intratumoral injection. The rheological study revealed that the gel was formed rapidly and recovered promptly to exhibit excellent injectable property. The investigation of interaction between DOX and gelator revealed that the $\Pi-\Pi$ stacking interaction gave great contribution to drug loading and sustaining release. Attributed to the synergistic percutaneous ethanol injection therapy and chemotherapy, even low dose of DOX loaded in LMWG exhibited satisfied therapeutic efficacy in necrosis of tumor tissue and tumor inhibition. The systemic toxicity of DOX in gel was reduced significantly in the evaluation of low body weight loss and long survival time. The histological analysis of tumor tissues revealed that the anticancer mechanism of the synergistic PEI and chemotherapy of LMWG was attributed to the proliferation inhibition and apoptosis of cancer cells.

\section{Acknowledgement}

The authors thank for the financial support of National Science Foundation of China (No. 51573111, 21672164), Program for Changjiang Scholars and Innovative Research Team in University (IRT-15R48), Ministry of Education of China (No. 20130181110038), and Natural Science Foundation of Zhejiang Province (LY15B020001).

\section{Supplementary Material}

Supporting information.

http://www.ntno.org/v01p0313s1.pdf

\section{Competing Interests}

The authors have declared that no competing interest exists.

\section{References}

1. Jeon MJ, Gordon AC, Larson AC, Chung JW, Kim YI, Kim D-H. Transcatheter intra-arterial infusion of doxorubicin loaded porous magnetic nano-clusters with iodinated oil for the treatment of liver cancer. Biomaterials. 2016; 88: 25-33.

2. Park W, Chen J, Cho S, Park S-j, Larson AC, Na K, Kim D-H. Acidic pH-triggered drug eluting nanocomposites for MRI monitored intra-arterial drug delivery to hepatocellular carcinoma. ACS Appl Mater Interfaces. 2016; 8: 12711-12719.

3. Poursaid A, Price R, Tiede A, Olson E, Huo E, McGill L, Ghandehari H, Cappello J. In situ gelling silk-elastinlike protein polymer for transarterial chemoembolization. Biomaterials. 2015; 57: 142-152

4. Zhao Y, Zheng C, Wang Q, Fang J, Zhou G, Zhao H, Yang Y, Xu H, Feng G, Yang $X$. Permanent and peripheral embolization: temperature-sensitive $p$ (N-isopropylacrylamide-co-butyl methylacrylate) nanogel as a novel blood-vessel-embolic material in the interventional therapy of liver tumors. Adv Funct Mater. 2011; 21: 2035-2042.

5. Sharma KV, Bascal Z, Kilpatrick H, Ashrafi K, Willis SL, Dreher MR, Lewis AL. Long-term biocompatibility, imaging appearance and tissue effects associated with delivery of a novel radiopaque embolization bead for image-guided therapy. Biomaterials. 2016; 103: 293-304.

6. Lilienberg E, Ebeling Barbier C, Nyman R, Hedeland M, Bondesson U, Axe $\square$ n $\mathrm{N}$, Lennernäs $\mathrm{H}$. Investigation of hepatobiliary disposition of doxorubicin following intrahepatic delivery of different dosage forms. Mol Pharm. 2013; 11: 131-144.

7. Poggi G, Quaretti P, Minoia C, Bernardo G, Bonora MR, Gaggeri R, Ronchi A, Saluzzo CM, Azzaretti A, Rodolico G. Transhepatic arterial chemoembolization with oxaliplatin-eluting microspheres (OEM-TACE) for unresectable hepatic tumors. Anticancer Res. 2008; 28: 3835-3842.

8. Buijs M, Reyes DK, Pawlik TM, Blackford AL, Salem R, Messersmith WA, Weekes CD, Mulcahy M, Kamel IR, Geschwind JFH. Phase 2 trial of concurrent bevacizumab and transhepatic arterial chemoembolization in patients with unresectable hepatocellular carcinoma. Cancer. 2013; 119: 1042-1049.

9. Fan H, Wang L, Feng X, Bu Y, Wu D, Jin Z. Supramolecular Hydrogel Formation Based on Tannic Acid. Macromolecules. 2017; 50: 666-676.

10. Cao W, Wan Y, Liang ZH, Duan YY, Liu X, Wang ZM, Liu YY, Zhu J, Liu XT, Zhang HX. Heated lipiodol as an embolization agent for transhepatic arterial embolization in VX2 rabbit liver cancer model. Eur J Radiol. 2010; 73: 412-419.

11. Lewis, A. L.; Dreher, M. R. Locoregional drug delivery using image-guided intra-arterial drug eluting bead therapy. Journal of Controlled Release. 2012; 161: 338-350.

12. Lewis, A. L.; Gonzalez, M. V.; Lloyd, A. W.; Hall, B.; Tang, Y.; Willis, S. L.; Leppard, S. W.; Wolfenden, L. C.; Palmer, R. R.; Stratford, P. W. DC Bead: In Vitro Characterization of a Drug-delivery Device for Transarterial Chemoembolization. Journal of Vascular and Interventional Radiology. 2006; 17: 335-342

13. Nicolini A, Crespi S, Martinetti L. Drug delivery embolization systems: a physician's perspective. Expert opinion on drug delivery. 2011; 8: 1071-1084.

14. Hong K, Khwaja A, Liapi E, Torbenson MS, Georgiades CS, Geschwind JFH. New intra-arterial drug delivery system for the treatment of liver cancer: preclinical assessment in a rabbit model of liver cancer. Clin Cancer Res. 2006; 12: 2563-2567.

15. Varela, M.; Real, M. I.; Burrel, M.; Forner, A.; Sala, M.; Brunet, M.; Ayuso, C.; Castells, L.; Montañá, X.; Llovet, J. M.; Bruix, J. Chemoembolization of hepatocellular carcinoma with drug eluting beads: Efficacy and doxorubicin pharmacokinetics. Journal of Hepatology. 2007; 46: 474-481. 
16. Morse DC, Silva E, Bartrom J, Young K, Bass EJ, Potter D, Bieber T. Improved bleeding scores using Gelfoam ${ }^{\circledR}$ Powder with incremental concentrations of bovine thrombin in a swine liver lesion model. J Thromb Thrombolysis. 2016:1-8.

17. Saralidze K, van Hooy-Corstjens CSJ, Koole LH, Knetsch MLW. New acrylic microspheres for arterial embolization: combining radiopacity for precise localization with immobilized thrombin to trigger local blood coagulation. Biomaterials. 2007; 28: 2457-2464

18. Wu X, He C, Wu Y, Chen X. Synergistic therapeutic effects of Schiff's base cross-linked injectable hydrogels for local co-delivery of metformin and 5-fluorouracil in a mouse colon carcinoma model. Biomaterials. 2016; 75: 148-162.

19. Kwon DY, Kwon JS, Park JH, Park SH, Oh HJ, Kim JH, Min BH, Park K, Kim MS. Synergistic anti-tumor activity through combinational intratumoral injection of an in-situ injectable drug depot. Biomaterials. 2016; 85: 232-245.

20. Wang C, Wang X, Dong K, Luo J, Zhang Q, Cheng Y. Injectable and responsively degradable hydrogel for personalized photothermal therapy. Biomaterials. 2016; 104: 129-137.

21. Kaplan JA, Barthélémy P, Grinstaff MW. Self-assembled nanofiber hydrogels for mechanoresponsive therapeutic anti-TNFa antibody delivery. ChCom. 2016; 52: 5860-5863.

22. Gao $\mathrm{W}$, Liang $\mathrm{Y}$, Peng $\mathrm{X}, \mathrm{Hu} \mathrm{Y}$, Zhang $\mathrm{L}, \mathrm{Wu} \mathrm{H}, \mathrm{He} B$. In situ injection of phenylboronic acid based low molecular weight gels for efficient chemotherapy. Biomaterials. 2016; 105: 1-11.

23. Patil SP, Kim SH, Jadhav JR, Lee JH, Jeon EM, Kim KT, Kim BH. Cancer-specific gene silencing through therapeutic siRNA delivery with $\mathrm{B}$ vitamin-based nanoassembled low-molecular-weight hydrogelators. Bioconjug Chem. 2014; 25: 1517-1525.

24. Nummelin S, Liljeström V, Saarikoski E, Ropponen J, Nykänen A, Linko V, Seppälä J, Hirvonen J, Ikkala O, Bimbo LM. Self-assembly of amphiphilic janus dendrimers into mechanically robust supramolecular hydrogels for sustained drug release. Chem-A Europ I. 2015; 21: 14433-14439.

25. Gupta S, Singh M, M AR, Yavvari PS, Srivastava A, Bajaj A. Interactions governing the entrapment of anticancer drugs by low-molecular-weight hydrogelator for drug delivery applications. RSC Adv. 2016; 6: 19751-19757.

26. Shi $Y$, van der Meel R, Theek B, Blenke EO, Pieters EHE, Fens Marcel HAM, Ehling J, Schiffelers RM, Storm G, van Nostrum CF, Lammers T, Hennink WE. Complete regression of xenograft tumors upon targeted delivery of paclitaxel via п-п stacking stabilized polymeric micelles. ACS Nano, 2015; 9: 3740-3752.

27. Deng X, Liang Y, Peng X, Su T, Luo S, Cao J, Gu Z, He B. A facile strategy to generate polymeric nanoparticles for synergistic chemo-photodynamic therapy. Chem Commun. 2015; 51: 4271-4274.

28. Yang $Y$, Wang $X$, Yang F, Shen H, Wu D. A Universal Soaking Strategy to Convert Composite Hydrogels into Extremely Tough and Rapidly Recoverable Double-Network Hydrogels. Adv Mater. 2016; 28: 7178-7184.

29. Bouguet-Bonnet S, Yemloul M, Canet D. New application of proton nuclear spin relaxation unraveling the intermolecular structural features of low-molecular-weight organogel fibers. J Am Chem Soc. 2012; 134: 10621-10627

30. Debnath S, Shome A, Dutta S, Das PK. Dipeptide-based low-molecular-weight efficient organogelators and their application in water purification. Chem- $A$ Europ J. 2008; 14: 6870-6881.

31. Escuder B, Llusar M, Miravet JF. Insight on the NMR study of supramolecular gels and its application to monitor molecular recognition on self-assembled fibers. J Org Chem. 2006; 71: 7747-7752.

32. Allix F, Curcio P, Pham QN, Pickaert G, Jamart-Gre $\square$ goire B. Evidence of intercolumnar $\Pi$ - $\Pi$ stacking interactions in amino-acid-based low-molecular-weight organogels. Langmuir. 2010; 26: 16818-16827.

33. Liu J, Xu F, Sun Z, Pan Y, Tian J, Lin HC, Li X. A supramolecular gel based on a glycosylated amino acid derivative with the properties of gel to crystal transition. Soft matter. 2016; 12: 141-148.

34. Foster JS, Zurek JM, Almeida NMS, Hendriksen WE, le Sage VAA, Lakshminarayanan V, Thompson AL, Banerjee R, Eelkema R, Mulvana H. Gelation landscape engineering using a multi-reaction supramolecular hydrogelator system. J Am Chem Soc. 2015; 137: 14236-14239.

35. Li N, Li N, Yi Q, Luo K, Guo C, Pan D, Gu Z. Amphiphilic peptide dendritic copolymer-doxorubicin nanoscale conjugate self-assembled to enzyme-responsive anti-cancer agent. Biomaterials. 2014; 35: 9529-9545

36. Liang Y, Peng X, Chen Y, Deng X, Gao W, Cao J, Chang J, Gu Z, He B. Chain length effect on drug delivery of chrysin modified mPEG-PCL micelles. RSC Adv. 2015; 5: 59014-59021.

37. Liang Y, Deng X, Zhang L, Peng X, Gao W, Cao J, Gu Z, He B. Terminal modification of polymeric micelles with $\Pi$-conjugated moieties for efficient anticancer drug delivery. Biomaterials. 2015; 71: 1-10.

38. Liang Y, Gao W, Peng X, Deng X, Sun C, Wu H, He B. Near infrared light responsive hybrid nanoparticles for synergistic therapy. Biomaterials. 2016; 100: $76-90$ 